\title{
Explaining the Roles of Social Media Marketing Activities in Improving Customer Commitment (Case Study: Digikala Online Store)
}

\author{
Parsa nikfetrat $^{\mathrm{a}}$, Ali Jahanbin ${ }^{\mathrm{b}}$, Reza kamali ${ }^{\mathrm{c}}$ \\ ${ }^{a}$ Master of Business Administration Marketing Orientation Islamic Azad University, Yasuj Branch \\ ${ }^{\mathrm{b}}$ Master of Business Administration International Orientation Islamic Azad University, Yasuj Branch \\ ${ }^{\mathrm{c}}$ Master of Business Administration International Orientation Islamic Azad University, Yasuj Branch
}

\begin{abstract}
The traditional methods of searching for information and buying items have become obsolete, and have created new social and economic consequences in various fields such as marketing and relevant activities due to social media in today's world; hence, the present study aimed to explain the roles of social media marketing activities in improving customer commitment by considering the role of brand equity as a mediating variable. The statistical population consisted of customers of Digikala online store as members of the Instagram page of this store. Due to the unknown population size, the statistical sample was determined to be equal to 384 according to the Morgan table. The data collection tool of the study included a standard questionnaire, and the data analysis method was based on confirmatory factor analysis and structural equations. The results indicated that social media marketing activities had positive and significant effects on brand equity dimensions (brand awareness, and brand image) that in turn had a positive and significant effect on customer commitment. Social media marketing affected customer commitment directly and mediated by brand equity.
\end{abstract}

Keywords: Marketing Activity; Social Media; Customer Commitment; Online Store

\section{Introduction and problem statement}

Many organizations believe that brands of their products and services are their most valuable assets. A strong brand creates value for both the customer and the organization. The service sector has had significant growth in recent years (Karimi, 2017). The development of the Internet and the emergence of online social media have created an appropriate infrastructure for public relations. Due to the expansion of popularity and use of social media, many companies use this communication infrastructure to achieve goals such as marketing, advertising, and interaction with consumers (Hosseinzadeh et al., 2016).

Social media, applications, platforms and online media are designed to facilitate interaction, collaboration and content sharing. Due to the exponential increase in the use of these social media, not only the users of existing social networks but also commercial companies and government organizations are connecting and using them as communication tools. Unlike individual users of social networks, these organizations actively use social media for advertising and marketing, which is to implement integrated marketing activities 
without time, space and media restrictions with much less effort and cost and cost. It has been done more economically than before (Kim and Ko, 2012). Social media has become one of the channels through which the consumer receives information about the goods or services he needs through these social media. Therefore, companies urgently need to recognize the impact of social media marketing activities on brand equity and customer commitment as their response to these activities (Breno, 2018).

Social media is a space for consumers to discuss and interact, interacting on a social media provides users with insight and understanding about the brand they want; These users communicate with each other in cyberspace and talk about a specific product or brand. These interactions fundamentally change the dynamic nature of the brand-customer relationship and also create user-generated content on social media (SEO and Park, 2018). With the spread of popularity and the use of social media, many companies are using this communication infrastructure to achieve goals such as marketing, advertising and interaction with consumers, because they have learned from experience that interaction with consumers Social media can be an effective tool to create awareness, interest and ultimately customer commitment (Hosseinzadeh et al., 2016).

This is important from the perspective that customer commitment is one of the most important assets of companies and organizations. Thus, how an organization looks and behaves has a direct impact on customer engagement (Swift, 2001). This psychological commitment of the customer reflects the desire for a lasting business relationship, which also takes into account the desire of people to be in this trustworthy relationship. What distinguishes the social media capability of the present era from the past is the context of the formation of social media and their internal communication mechanisms. These capabilities have given these networks the ability to change traditional power equations. The main features of social media are cyberspace in its flexibility (reconstruction and responsiveness to environmental changes (scalability), shrinking and enlarging (and the ability to survive without dependence on a single centrality (Stephen, 2011).

Important for these networks is the entry of new actors and the existence of a wide space for interaction with others, free production of content, sharing of knowledge and information, and their independence from official centers of power. The interests of the new actors are limited, and the network of relations between the actors has created a huge social capital, because on the one hand, with the expansion of information dissemination intermediaries, the concentration of power in controlling information has disappeared; Formed in social media around shared values, ideas, and interests, they have emerged as powerful actors in the social, cultural, political, and economic spheres (Lee, 2017).

Digikala online store is the largest market and online store in Iran, which has more than 5.4 million daily visitors and has an $85 \%$ share of the online sales market in Iran. DigiCala's business model is a mixture of virtual marketplace and retail and includes various sections and collections, some of which are operating within the platform itself and some with different themes and outside the DigiCala store platform, such as DigiStyle, DigiNext, Fidebo, Comeda, Pindo and Digi Express are active members of this group. In the present study, considering the importance of online stores while increasing the role of marketing activities in introducing and developing their markets, researchers seek to answer the main question: 1) What is the impact of social media marketing activities on customer 
commitment? 2) What is the effect of brand equity variable on the relationship between social media marketing activities and customer commitment?

\section{Social media and marketing activities}

Social media is a new generation of websites that are in the spotlight of the World Wide Web these days. Such sites are based on the formation of online communities, and each brings together a group of Internet users with a specific feature. Social media is considered as a type of social media that has enabled a new way of communicating and sharing content on the Internet (Domingos, 2011). Social media is a social structure made up of nodes (usually individual or organizational) that are connected by one or more specific types of dependencies. In other words, a social media is a site or collection of sites that users who like to share their interests, thoughts, activities with others and others to share with them (Algheimer et al., 2005). Social media is a group of new types of online media that have all or some of the following features: 1) the ability to participate; 2) openness; 3) two-way communication; 4) formation of online communities; 5) Ability to communicate (Mahdavifar, 2014). Social media is obsolete in the traditional way of finding information and buying items, and thus creating new social and economic consequences. Social media will become both easier and more important in the future, as many companies will use it in external advertising, marketing, customer management, and as an internal channel for employee communication (SEO). And Park, 2018). There are many types of social media, including blogs, social networks such as Facebook, Telegram, WhatsApp and Instagram, photo and video sharing sites (YouTube and Abroad), podcasts and Etc.

(Fakhari et al., 2014). Kim and Ko (2012) categorize the characteristics of social media marketing activities into several categories, including entertainment, interaction, up-todateness, customization, and word of mouth. Sao et al. (2015) acknowledge that an effective way for a brand to be useful in the social media environment is to somehow gain the credibility of the people who are the source of word of mouth on social media. Being known by friends is an important motivator for people, and brands that allow their users to achieve this motivation give them great value. When users make this recognition public, they turn it into word of mouth. In addition, in terms of human perception, virtual elements play an important role in facilitating word of mouth. This belief is actually based on user behavior (Ahmado et al., 2015).

Social media marketing is an internet marketing strategy that leads the business in the organization and reaches the target community. Social media marketing includes: an attempt to use social media to convince a company's consumers to use Products or services are valuable. The main goal of social media marketing is to create a business based on customer orientation and a company's reputation for business development and management (Stephen, 2011). The most important benefits of using social media marketing are: Increased brand recognition in social media marketing; 2) increase customers' conscientiousness towards the brand; 3) Opportunities to turn viewers of marketing activities on social media into brand customers; 4) High conversion rate of the number of customers generated in front of visitors; 
5) increase brand credibility; 6) increase inbound traffic; 7) reduce marketing costs; 8) Increase search engine rankings, 9) Interact more and more effectively with customers

\section{2-1. Customer commitment and the components that affect it}

From a behavioral science perspective, customer commitment as a psychological structure of individual requirements is in solidarity with the individual or business relationship.

This psychological commitment of the client reflects the desire for a lasting business relationship, which also takes into account the desire of people to be in this trustworthy relationship (Kelly et al., 2010). Commitment is an important structure for a long-term relationship and means continuing the relationship with the partner, which if guaranteed, maximum efforts will be made to maintain it (Kim et al., 2006). Commitment can be defined as a general indicator of social exchange. Vasudwan et al. (2006) believe that when business parties are committed to each other, they are more willing to cooperate, meet the other party's needs, share information, and solve problems together. Many experts believe that customers who perceive a social interaction as evidence of a higher level of commitment are more likely to cooperate more with the organization and more willing to work as a representative of the organization. (Ding et al., 2016). The following table summarizes some of the most important aspects of customer commitment:

Table 1. Dimensions of customer commitment

\begin{tabular}{|l|c|}
\hline \multicolumn{1}{|c|}{ Dimensions } & Owner \\
\hline $\begin{array}{l}\text { 1) Emotional commitment: refers to an affiliation and belonging to the organization } \\
\text { that is based on the desire of the individual; 2) Continuous commitment: refers to a } \\
\text { cost-dependent dependence that the individual feels should stay with the } \\
\text { organization; 3) Normative commitment: refers to a commitment-oriented } \\
\text { dependence on the organization. }\end{array}$ & $\begin{array}{c}\text { Mir and } \\
\text { Allen }\end{array}$ \\
\hline $\begin{array}{l}\text { Commitment is defined as a force that binds a person to continue purchasing a } \\
\text { service from a service provider and its source is 1) emotional and due to the person's } \\
\text { personal desire or desire, or 2) normative and due to the person's requirements, or }\end{array}$ & $\begin{array}{c}\text { Mir and } \\
\text { 3) continuous. And is due to individual needs. }\end{array}$ \\
\hline $\begin{array}{l}\text { Commitment has three aspects: 1) From an instrumental point of view: An } \\
\text { instrument looks at commitment from a computational point of view and that one } \\
\text { party pays attention to its long-term interests in remaining committed. 2) From a } \\
\text { behavioral point of view: refers to a type of commitment to the organization, to a } \\
\text { specific goal or person, which is the goal or individual because of the organization } \\
\text { itself, regardless of its instrumental value. 3) Temporal view: in terms of long-term } \\
\text { commitment meaning Notes that the inputs and outputs that enter and exit the } \\
\text { relationship must be continuous over time }\end{array}$ & al \\
\hline
\end{tabular}

1. Brand equity Brand equity is a set of assets and liabilities associated with a brand, name and symbol that increases or decreases the value of a product or service for an organization or its customers (Farhangi et al., 2015). The issue of brand equity has taken root in the principles of marketing. Traditionally, brand equity has been studied in the field of products 
and often in the field of consumer products (Breno, 2018). The importance of brand equity is due to the quality of information content that is provided to the consumer when processing information about a particular brand (Chiu et al., 2010). Accordingly, brand equity from a customer perspective is a different effect that brand awareness has on customer response to that brand marketing. Various experts have defined different dimensions for brand equity, the most important of which are:

Brand awareness: Brand awareness is the ability to recognize (recognize) and remind potential buyers about a brand, as a member of a particular category of products. Consumerbased brand equity is created when the consumer has a high level of brand awareness and familiarity, as well as unique, desirable and powerful associations in mind.

Brand association: Brand association is everything related to the brand in memory. Brand compatibility and association may be seen as all forms and features associated with a product or aspects independent of the product itself. Association is the basis for purchasing decisions for brand loyalty and also creates value for the company and its customers (Karroubi et al., 2016).

\section{2-2. Empirical background of the research}

The following table (2) lists some of the most relevant research conducted under the title of the present study:

Table 2. Empirical background of the research

\begin{tabular}{|l|c|c|}
\hline \multicolumn{1}{|c|}{ findings } & Research title & Researcher \\
\hline $\begin{array}{l}\text { Up-to-date is the most important component of } \\
\text { social media marketing activities and aviation } \\
\text { social media marketing activities have a } \\
\text { significant impact on brand and brand awareness. } \\
\text { In addition, the results showed that brand and } \\
\text { image awareness significantly affects } \\
\text { commitment. }\end{array}$ & $\begin{array}{c}\text { The effect of social media } \\
\text { marketing activities on brand } \\
\text { equity and customer response } \\
\text { in airlines }\end{array}$ & $\begin{array}{c}\text { SEO and park } \\
(2018)\end{array}$ \\
\hline $\begin{array}{l}\text { Brand personality has a significant effect on } \\
\text { brand equity through brand trust, brand } \\
\text { attachment and commitment to the brand. }\end{array}$ & $\begin{array}{c}\text { The impact of brand } \\
\text { personality on brand equity } \\
\text { through brand trust, brand } \\
\text { attachment and brand } \\
\text { commitment }\end{array}$ & $\begin{array}{c}\text { Ahmed and } \\
\text { (2015) }\end{array}$ \\
\hline $\begin{array}{l}\text { Brand differentiation and trust in the brand has a } \\
\text { significant impact on customers' relationship } \\
\text { with the brand and the quality of services } \\
\text { perceived by them. In addition, the high brand } \\
\text { equity in a hotel leads to a high level of } \\
\text { commitment in the hotel staff to its brand. }\end{array}$ & $\begin{array}{c}\text { The impact of service brand } \\
\text { equity on brand commitment } \\
\text { by hotel staff in India }\end{array}$ & Sano (2015) \\
\hline $\begin{array}{l}\text { There is a significant positive relationship } \\
\text { etween media advertisements with brand equity } \\
\text { brand loyalty, brand association, brand awareness }\end{array}$ & $\begin{array}{c}\text { Relationship between media } \\
\text { advertisements with brand } \\
\text { equity from the perspective of }\end{array}$ & $\begin{array}{c}\text { Alizadeh } \\
\text { Jananian (2017) }\end{array}$ \\
\hline
\end{tabular}




\begin{tabular}{|l|c|c|}
\hline $\begin{array}{l}\text { Ind perceived quality of the brand) from the } \\
\text { perspective of customers of sports stores in Tabriz. }\end{array}$ & $\begin{array}{c}\text { customers of sports stores in } \\
\text { Tabriz }\end{array}$ & \\
\hline $\begin{array}{l}\text { The tendency to use online social networks has a } \\
\text { significant effect on brand equity and brand } \\
\text { performance as well as brand equity on brand } \\
\text { performance. }\end{array}$ & $\begin{array}{c}\text { The effect of the desire to use } \\
\text { online social networks on } \\
\text { brand performance and } \\
\text { customer-based brand equity }\end{array}$ & $\begin{array}{c}\text { Oriental } \\
\text { (2016), }\end{array}$ \\
\hline $\begin{array}{l}\text { There is a relationship between brand equity and } \\
\text { consumer behavior and customer responses } \\
\text { (commitment) with emphasis on the role of } \\
\text { marketing mix factors. }\end{array}$ & $\begin{array}{c}\text { The effect of brand equity on } \\
\text { consumer behavior and } \\
\text { customer responses with } \\
\text { emphasis on the role of } \\
\text { digital product marketing mix } \\
\text { factors }\end{array}$ & $\begin{array}{c}\text { Bazai et al. } \\
\text { (2015), }\end{array}$ \\
\hline $\begin{array}{l}\text { Advertising has a positive and significant effect } \\
\text { on consumer response. Also, advertising is } \\
\text { effective on consumer response through the } \\
\text { mediating role of customer-based brand value } \\
\text { and each of its dimensions. }\end{array}$ & $\begin{array}{c}\text { The Role of Customer-Based } \\
\text { Brand Value in the Effect of } \\
\text { Advertising on Consumer } \\
\text { Response in Tourism and } \\
\text { Travel Agencies }\end{array}$ & $\begin{array}{l}\text { Kafashopour } \\
\text { et al. (2014), }\end{array}$ \\
\hline
\end{tabular}

\section{Research methodology}

The research is applied in terms of purpose and survey-descriptive in terms of method and nature. The statistical population of this study is the customers of Digi Kala online store who are active in social media. Due to the unknown size of the population, the statistical sample according to Morgan table was confirmed as 384 people. Data collection was done by library method (referring to the library, using article database, dissertation database and reputable sites. Also, in the field method, the researcher sent an electronic questionnaire directly to the members of the Instagram page of Digi Kala users. In this study, social media marketing activities with five components including entertainment, interaction, up-to-dateness, customization and perceived risk are questioned with 11 questions and the other three elements including brand awareness, brand image and commitment (each). 3 questions) are evaluated with 9 questions, which includes a total of 20 questions. The Likert scale of questions is rated from 1 ("strongly disagree") to 5 ("strongly agree") based on the Likert scale. The questionnaire on the effect of social media marketing activities on brand equity and customer response in previous research has been reviewed by researchers (SEO and Park, 2018 and Wang, 2015) and has been confirmed by relevant and relevant professors. Its reliability was calculated to be 0.78 using Cronbach's alpha measurement method. The data were performed using two methods of descriptive statistics and inferential and analytical statistics of Spss and Amos software. 


\section{Findings}

The results of statistical findings of this research are as follows in Table (3): Table 3. Demographic features of the study.

Table 3. Demographic features of the research

\begin{tabular}{|c|c|c|c|}
\hline Frequency & Abundance & Variable & \multirow{3}{*}{$\begin{array}{c}\text { Gender of } \\
\text { respondents }\end{array}$} \\
\hline $0 / 53$ & 203 & Man & \\
\hline $0 / 47$ & 181 & Female & \\
\hline $0 / 335$ & 129 & $20-35$ & \multirow{4}{*}{$\begin{array}{l}\text { Age of } \\
\text { respondents }\end{array}$} \\
\hline $0 / 307$ & 118 & $36-50$ & \\
\hline $0 / 195$ & 75 & $51-65$ & \\
\hline $0 / 161$ & 62 & 66 and above & \\
\hline $0 / 255$ & 98 & Diploma and less & \multirow{4}{*}{ Education } \\
\hline $0 / 291$ & 112 & Associate Degree & \\
\hline $0 / 299$ & 115 & Masters & \\
\hline $0 / 146$ & 56 & Master and above & \\
\hline $0 / 305$ & 117 & Less than 60 minutes & \multirow{4}{*}{$\begin{array}{l}\text { Use social } \\
\text { media daily }\end{array}$} \\
\hline $0 / 351$ & 135 & Between 61 and 120 minutes & \\
\hline $0 / 219$ & 84 & Between 121 and 240 minutes & \\
\hline $0 / 125$ & 48 & More than 240 minutes & \\
\hline
\end{tabular}

Confirmatory factor analysis of research Before evaluating the proposed structural model, it is necessary to examine the significance of regression weight (factor load) of different constructs of the questionnaire in predicting the relevant items to ensure the suitability of measurement models and the acceptability of their indicators in measuring structures. This was done using confirmatory factor analysis (CFA) technique and AMOS software. Then, each of the measurement models was examined separately and then the general measurement model was examined. Two KMO indices and Bartlett test are used to evaluate the sampling adequacy indices. The KMO index is an indicator of the adequacy of sampling. This index is in the range of zero to one. If the value of the index is close to one, the data are suitable for factor analysis, otherwise (usually less than 0.5 ) the results of factor analysis are not very suitable for the data.

Table 4. Bartlett test results and KMO index for research variables

\begin{tabular}{|c|c|c|}
\hline Bartlett test & KMO index & Variables \\
\hline $0 / 000$ & $0 / 714$ & Social media marketing \\
\hline $0 / 000$ & $0 / 585$ & Brand awareness \\
\hline $0 / 000$ & $0 / 694$ & Brand image \\
\hline $0 / 000$ & $0 / 684$ & obligation \\
\hline
\end{tabular}

The results of Bartlett and KMO test as sampling adequacy indices show that the values of both indices are at the desired level. The KMO standard value for all variables is more than 0.5 , and the significance value of Bartlett test for data normality in Amos software is measured by two indices of elongation and skew. The skewness coefficient and the 
elongation coefficient are the two basic indicators of data distribution that by having these indicators, it can be realized whether the data distribution is normal or not.

Table 5. Results of Confirmatory Factor Analysis (CFA) for questionnaire items

\begin{tabular}{|c|c|c|c|c|c|c|c|}
\hline Result & $\begin{array}{c}\text { meani } \\
\text { ngful }\end{array}$ & $\begin{array}{c}\text { Bar } \\
\text { Factor }\end{array}$ & Elongation & choleghi & Item & Dimensions & $\begin{array}{c}\text { Variable } \\
\text { name }\end{array}$ \\
\hline Meaningful & $0 / 001$ & $0 / 726$ & $0 / 254$ & $-0 / 914$ & Q1 & Entertainme & \multirow{11}{*}{$\begin{array}{c}\text { Social } \\
\text { media } \\
\text { marketin } \\
\quad \mathrm{g}\end{array}$} \\
\hline Meaningful & $0 / 001$ & $0 / 733$ & $-0 / 849$ & $-0 / 441$ & Q2 & & \\
\hline Meaningful & $0 / 001$ & $0 / 566$ & $-0 / 389$ & $-0 / 529$ & Q3 & \multirow{3}{*}{ Interaction } & \\
\hline Meaningful & $0 / 001$ & $0 / 733$ & $-0 / 423$ & $-0 / 763$ & Q4 & & \\
\hline Meaningful & $0 / 001$ & $0 / 577$ & $-0 / 821$ & $-0 / / 278$ & Q5 & & \\
\hline Meaningful & $0 / 001$ & $0 / 863$ & $0 / 546$ & $-0 / 190$ & Q6 & \multirow[b]{2}{*}{ up to date } & \\
\hline Meaningful & $0 / 001$ & $0 / 763$ & $0 / 813$ & $-0 / 294$ & Q7 & & \\
\hline Meaningful & $0 / 001$ & $0 / 769$ & $0 / 419$ & $-0 / 163$ & Q8 & \multirow{4}{*}{$\begin{array}{c}\begin{array}{c}\text { Customizati } \\
\text { on }\end{array} \\
\begin{array}{c}\text { Perceived } \\
\text { risk }\end{array} \\
\end{array}$} & \\
\hline Meaningful & $0 / 001$ & $0 / 984$ & $-0 / 354$ & $-0 / 326$ & Q9 & & \\
\hline Meaningful & $0 / 001$ & $0 / 857$ & $0 / 912$ & $0 / 351$ & Q10 & & \\
\hline Meaningful & $0 / 001$ & $0 / 783$ & $0 / 248$ & $0 / 515$ & Q11 & & \\
\hline Meaningful & $0 / 001$ & $0 / 556$ & $0 / 327$ & $-0 / 613$ & Q12 & \multirow{3}{*}{$\begin{array}{c}\text { Brand } \\
\text { awareness }\end{array}$} & \multirow{6}{*}{$\begin{array}{l}\text { Brand } \\
\text { equity }\end{array}$} \\
\hline Meaningful & $0 / 001$ & $0 / 697$ & $-0 / 904$ & $-0 / 453$ & Q13 & & \\
\hline Meaningful & $0 / 001$ & $0 / 646$ & $0 / 113$ & $-0 / 871$ & Q14 & & \\
\hline Meaningful & $0 / 001$ & $0 / 848$ & $0 / 478$ & $0 / 109$ & Q15 & \multirow{3}{*}{$\begin{array}{l}\text { Brand } \\
\text { image }\end{array}$} & \\
\hline Meaningful & $0 / 001$ & $0 / 898$ & $-0 / 113$ & $0 / 038$ & Q16 & & \\
\hline Meaningful & $0 / 001$ & $0 / 823$ & $-0 / 866$ & $0 / 451$ & Q17 & & \\
\hline Meaningful & $0 / 001$ & $0 / 847$ & $0 / 463$ & $0 / 659$ & Q18 & & \multirow{3}{*}{$\underset{n}{\text { obligatio }}$} \\
\hline Meaningful & $0 / 001$ & $0 / 641$ & $0 / 322$ & $0 / 928$ & Q19 & & \\
\hline Meaningful & $0 / 001$ & $0 / 729$ & $-0 / 393$ & $0 / 578$ & Q20 & & \\
\hline
\end{tabular}

As shown in the table above, the amount of distortion and skewness of all data is between $1 \%$, which indicates that the data is normal. Also, in the fitted factor analysis model, the factor load of all items is significant at the confidence level of 0.95 . Therefore, none of the questionnaire items were deleted. If the general indicators were acceptable or in other words, the theoretical model was approved, then the relationships within the model can be addressed. Existence of these coefficients (coefficients of effect of operating loads) of the partial index $P$ is used, the value of which is less than 0.05 for acceptable values. Table $4-10$ shows the model fit indices with the desired values. 
Table 6. Indicators of fitting the theoretical model of research

\begin{tabular}{|c|c|c|c|}
\hline $\begin{array}{c}\text { The value } \\
\text { obtained in the } \\
\text { model }\end{array}$ & The ideal amount & Acceptable amount & Index name \\
\hline 73 & - & - & Degree of freedom $(\mathrm{df})$ \\
\hline $192 / 517$ & $0 \leq \chi^{2} \leq 2 \mathrm{df}$ & $2 \mathrm{df} \leq \chi^{2} \leq 3 \mathrm{df}$ & Chi-square $\left(\chi^{2}\right)$ \\
\hline $2 / 656$ & $0 \leq \chi^{2} / d f \leq 2$ & $2<\chi^{2} / d f \leq 3$ & Optimized Chi-square $\left(\mathrm{df} / \chi^{2}\right)$ \\
\hline $0 / 841$ & $.95 \leq G F I \leq 1.00$ & $.80 \leq \mathrm{GFI}<.95$ & Goodness of Fit $((\mathrm{GFI})$ \\
\hline $0 / 083$ & $0 \leq R M R \leq .05$ & $0<R M R \leq .10$ & $\begin{array}{c}\text { Root of the mean squares of the } \\
\text { remaining RMR }\end{array}$ \\
\hline $0 / 911$ & $.97 \leq C F I \leq 1.00$ & $.90 \leq \mathrm{CFI}<.97$ & Adaptive Fit Index $(\mathrm{CFI})$ \\
\hline $0 / 079$ & $0 \leq R M S E A \leq .05$ & $.05<R M S E A \leq .08$ & $\begin{array}{c}\text { Root of Mean Squares Estimation } \\
\text { Error (RMSEA) }\end{array}$ \\
\hline $0 / 381$ & $.60 \leq P G F I \leq 1.00$ & $.50 \leq \mathrm{PGFI}<.60$ & Brief Fit Goodness Index (PGFI) \\
\hline $0 / 658$ & $.60 \leq P N F I \leq 1.00$ & $.50 \leq \mathrm{PNFI}<.60$ & $\begin{array}{c}\text { Normalized Concise Fit Index } \\
\text { (PNFI) }\end{array}$ \\
\hline
\end{tabular}

Theoretical model The theoretical model of research is an acceptable model, so we can now deal with the relationships within the model and the values of the regression coefficient between the hidden variables. To test the hypothesis, a partial index ( $\mathrm{p}$-value) and a significant number have been used, and the condition for a relationship to be significant is that the value of the first index ( $\mathrm{p}$-value) for the desired relationship is less than 0.05 or the value of the second index ( $\mathrm{t}$-value) greater than $1.96 \%$.

\section{4-1. Test of research hypotheses}

The following is shown in Table (7), a summary of the results of regression coefficients and the significance of research variables:

Table 7. Regression coefficients and significance of research variables

\begin{tabular}{|c|c|c|c|l|c|}
\hline Result & $\begin{array}{c}\text { Meaningful } \\
\text { number }\end{array}$ & $\begin{array}{c}\text { p- } \\
\text { value }\end{array}$ & $\begin{array}{c}\text { Path } \\
\text { coefficient }\end{array}$ & \multicolumn{1}{|c|}{ Direct route } & Hypothesis \\
\hline Meaningful & $5 / 15$ & $0 / 000$ & $0 / 74$ & $\begin{array}{l}\text { Social media marketing } \\
\text { activities } \rightarrow \text { Brand } \\
\text { awareness }\end{array}$ & 1 \\
\hline Meaningful & $4 / 912$ & $0 / 000$ & $0 / 53$ & $\begin{array}{l}\text { Social media marketing } \\
\text { activities } \longrightarrow \text { Brand image }\end{array}$ & 2 \\
\hline Meaningful & $2 / 657$ & $0 / 000$ & $0 / 26$ & $\begin{array}{l}\text { Brand awareness } \rightarrow \\
\text { Customer commitment }\end{array}$ & 3 \\
\hline Meaningful & $8 / 315$ & $0 / 000$ & $0 / 79$ & $\begin{array}{l}\text { Brand image } \rightarrow \text { Customer } \\
\text { commitment }\end{array}$ & 4 \\
\hline Meaningful & $2 / 949$ & $0 / 000$ & $0 / 38$ & $\begin{array}{l}\text { Social media marketing } \\
\text { activities } \rightarrow \text { Brand equity } \\
\text { (brand image) } \rightarrow \text { Customer } \\
\text { commitment }\end{array}$ & 5 \\
\hline
\end{tabular}




\section{Discussion and conclusion}

Customers as the intangible assets of a company should be attracted and retained with prudence and thought and maximized like financial assets. Today, our world is facing a new and rapidly spreading phenomenon in the Internet space called social media. Social media, applications, platforms and online media are designed to facilitate interaction, collaboration and content sharing. Due to the exponential increase in the use of these social media, not only users of existing social networks but also commercial companies and government organizations are connecting and using them as communication tools. Therefore, the research of the present study was conducted with the main purpose of examining social media marketing activities on customer commitment. In the following, we will examine the test results of each of the hypotheses:

\section{Hypothesis 1) Social media marketing activities have a significant effect on brand awareness.}

Based on the results, considering that the significant number is out of the range of 1.96 , social media marketing activities have a positive and significant effect on the brand awareness of the studied customers. This finding is consistent with the results of studies by Azadi et al. (2014), Fakhari and Danaei (2014) and SEO and Park (2018). Therefore, when the customer considers the use of social media by the business complex as something new, as a result of which it is possible to discuss and exchange ideas with others who have similar interests with him, more knowledge and awareness than the online store of Digi Kala Becomes.

\section{Hypothesis 2) Social media marketing activities have a significant effect on brand image.}

The results of data analysis showed that the significant number outside the range is 961.96 , as a result of social media marketing activities have a positive and significant effect on the brand image of the studied customers. In other words, the more social media marketing activities, the more the brand image of the customers of this complex. This finding is in line with the results of Fakhari and Danaei (2014) as well as SEO and Park (2018).

\section{Hypothesis 3) Brand awareness has a significant effect on customer commitment}

The results of data analysis showed that the significant number outside the range is 961.96 , so brand awareness has a positive and significant effect on customer commitment. In other words, the more brand awareness, the greater the commitment of the customers of this complex. This result is directly in line with the research of Kafashpour et al. (2014), Kimpakorn and Thakur (2010) as well as SEO and Park (2018).

Hypothesis 4) Brand image has a significant effect on customer commitment. 
The significant number outside the range is 961.96 , so the brand image has a positive and significant effect on customer commitment. In other words, the better the brand image, the greater the commitment of the customers of this complex. This result is directly in line with the research of Kimpakorn and Thakur (2010) as well as SEO and Park (2018). This finding is also consistent with the results of studies by Dehdashti et al. (2012) and Gilani Nia and Mousavian (2010).

\section{Hypothesis 5) Brand equity (brand awareness and image) mediates the relationship between social media marketing activities and customer commitment.}

The results of data analysis show that social media marketing activities affect customer commitment due to brand equity. Since the t-value is equal to 2.949 and out of the range of 96 1.96, it can be concluded that social media marketing activities by increasing brand awareness and promoting the brand image, are able to commit the customers of Digikala online store. Increase. This result is completely consistent only with the study of SEO and Park (2018), but as similar studies, the following can be mentioned: Sharghi (2016) and Kafashpour et al. (2014) are consistent. Therefore, according to the research findings, it is suggested that the managers and marketers of Digi Kala online store diversify the maximum use of online marketing and various types of social media and encourage customers by offering special discounts if they share their experiences from the store. On social networks.

\section{Resources}

Ahmad, A., \& Thyagaraj, K. S. (2015). Impact of brand personality on brand equity: The role of brand trust, brand attachment, and brand commitment. Indian Journal of Marketing, 45(5), 14

Algesheimer, R., Dholakia, U. M., \& Herrmann, A. (2005). The social influence of brand community: Evidence from European car clubs. Journal of marketing, 69(3), 19-34

Bruno, G., Aikaterini, M., Daniele, P., Joonas, R., Gaetano, A., Raffaele, D., Rahul, S. (2016). Social media marketing efforts of luxury brands: influence on brand equity and consumer behavior. J. Bus. Res. 69 (12), 5833-5841.

Chiu, K. K. S., Hsu, M. K., Lin, R. J., \& Huang, L. H. (2010). Power of branding on internet service providers. Journal of Computer Information Systems, 50(3), 112-120

Cultural, A. And Abedini, R. (2015). The effect of mixed media elements on the brand equity of services (Case study of Sina Bank). Journal of Marketing Management, 26, 48-74.

Ding, Y., \& Keh, H. T. (2016). A re-examination of service standardization versus customization from the consumer's perspective. Journal of Services Marketing, 30(1), 16-

Domingos, P. (2011). Mining Social Networks Viral Marketing Department of Computer Science and Engineering, University Of Washington.

Fakhari, M; And Hemmati, m. (2017). Investigating the role of social media-based marketing activities on purchasing decision-making through brand equity, First National Conference on Marketing Research, Tehran, Narkish Information Institute.

Hosseinzadeh, S., Darloo Treasury, M. And Andalib, A. (2016). The Role of Online Social Media in Improving Marketing Strategies, 2nd International Conference on Web Research, Tehran, University of Science and Culture 
Karroubi, M., Bahari, J., Bahari, Sh., Bazleh, M. And Bahari, h. (2016). Investigating the Role of Customer-Based Brand Value in the Effect of Advertising on Consumer Response (Case Study: Akbar Jojeh Chain Restaurants). Journal of Hospitality and Hospitality Studies, 1 (2), 123-140.

Karimi, M. (2017). Investigating the effect of food brand equity dimensions on brand preference with the mediating role of perceived physical risk and perceived brand value, M.Sc. Thesis, Ferdowsi University of Mashhad.

Kim, A. J., \& Ko, E. (2012). Do social media marketing activities enhance customer equity? An empirical study of luxury fashion brand. Journal of Business Research, 65(10), 14801486

Kim, S. (2006). Public service motivation and organizational citizenship behavior in Korea. International journal of manpower, 27(8), 722-740

Mahdavi Fard, A. (2014). Social media in marketing research; Roles, functions and concepts. National Conference on Marketing Research. Shahid Beheshti International Conference Center.

Seo, E. J., \& Park, J. W. (2018). A study on the effects of social media marketing activities on brand equity and customer response in the airline industry. Journal of Air Transport Management, 66, 36-41.

Stefons, M. (2011). Marketing Action in Networks, Europian Jurnal Of Marketing 40

Swift, R. S. (2001). Accelerating customer relationships: Using CRM and relationship technologies. Prentice Hall Professional 